\title{
Breakdown in Monitoring Project Performance to Reduce Transaction Cost in Public Sector Construction Projects: A Case Study from Pakistan
}

\author{
* Zaigham Ali (Corresponding Author) \\ ** Ammar Hussain \\ *** Zubair Ahmed
}

\begin{abstract}
The purpose of this research is to break down the monitoring process to explore the problems which impede cost efficiency in contract monitoring in a developing country, such as Pakistan. This research investigated the issues and challenges to the cost-efficient and effective implementation of project monitoring systems in public sector construction projects in Pakistan. This study uses the transaction cost economics (TCE) lens, to explore the project monitoring process of construction projects, 25 interviews with Engineers and Associate engineers were conducted from public sector construction projects. Qualitative research was performed, and thick qualitative data has been coded, categorized, analyzed, and concluded. The study concluded that in principle, project monitoring contributes to reduced transaction costs, depending on how efficiently governance arrangements are made. Hurdles related to weak governance in the organization significantly increase the postcontract transaction cost (TC). As a result of the analysis, multiple issues have been identified from the study such as Political realities, capacity building, resource constraints, administrative issues, mutual dependency, and department coordination has a direct influence on the TCs in construction projects. The result of this study provides a deeper understanding and clear roadmap of the ongoing monitoring practices and processes in the public sector construction projects. It identifies the problems and issues of the monitoring process in the construction industry of developing countries which potentially causes to increase in the total project cost.
\end{abstract}

Keywords: Construction Projects, Transaction Cost, Project Monitoring, Governance, Contracts Introduction

Project monitoring is the stage of the project lifecycle which is unaddressed and forgotten in the process of planning (Seasons, 2003). Design-bid-build (DBB) projects in the construction industry are less exposed to external influence during the design phase and more exposed to externalities when services are contracted out. An effective monitoring mechanism is required to improve agent (contractor) performance (Brown \& Potoski, 2003). In this study, project monitoring refers to the regular collection and analysis of information and to benchmarking against a set of plans to compare conformity with predefined standards (Seasons, 2003). But in practice, the project monitoring process is often not taken seriously during its execution, which leads to serious outcomes (Meeampol \& Ogunlan, 2014). Project monitoring can act as an early warning tool (Abdul-Rahman et al., 2006) that can help controlling project costs during the project's realization (Al-Jibouri, 2003). Moreover, project monitoring helps with the early identification of factors that may jeopardize overall performance. It is further argued that monitoring as an understudied phase in the project cycle which could give practitioners a significant amount of information and resource that can help overcome the various issue (Abdul-Rahman et al., 2006), and also assist in eradicating corrupt practices (Lengwiler $\&$ Wolfstetter, 2006).

Project performance monitoring is being practiced in construction projects around the world. Some authors have used measures for project performance. For instance, Avery (2000) suggested establishing a feedback system. Other studies used activity base ratios, earned value management (EVM), forecasting and variances as a tool (Al-Jibouri, 2003; Bower \& Finegan, 2009). In general,

* Department of Business Management, Karakoram International University Email: Zaigham.ali@kiu.edu.pk

** Department of Business Management, Karakoram International University Email: Dr.Ammar@kiu.edu.pk

***Department of Sociology, Karakoram International University Email: Zubair.ahmed@kiu.edu.pk 
quantitative statistical techniques were used in projects to evaluate the effectiveness of project performance (Hall \& Rimmer, 1994). These studies show the general perspective of tracking project performance focusing on the mix of cost, time, and objective quantitatively is indeed helpful but insufficient in the construction industry unless details qualitative analysis of the monitoring process is not made. Construction projects are executed in the natural environment and prone to continuous schedule delays and workmanship quality due to which quality control systems remain ambiguous (Nicholas \& Steyn, 2012). Thus, a prevalent project monitoring system in developing countries needed to explore because of its weaknesses. The monitoring system is designed in any project to monitor the project performance, which is sometimes not followed (Khoshgoftar, Bakar, \& Osman, 2010). Besides that, the field staff deputed by the organization for project monitoring take those mechanized monitoring systems merely a reporting tool and it is observed that professional knowledge does not always practice (Lobb-rabe, 2000). The project monitoring activity became end rather than means that limit to take corrective action on project sites (Abbot \& Guijt, 1998). Therefore, maintaining the initial project cost becomes challenging for practitioners despite prevailing project monitoring processes in construction projects.

Anecdotal evidence shows that monitoring is usually neglected during project execution, leading to severe consequences (Meeampol \& Ogunlan, 2009). For instance, a case reported in an online newspaper found that the Planning and Development Department $(\mathrm{P} \& \mathrm{D}$, apex authority for fund allocation) of Gilgit-Baltistan (GB), Pakistan had rejected a newly constructed high school building in the village Sost, Gojal. The P\&D Department found that the newly built building did not meet the standards. As per initial contract specifications (PC-1) in 2006, the project was approved with a total budget of PKRs. $5.5(\mathrm{~m})$ for the construction of classrooms, a laboratory, and a library in the existing school. The entire project budget of PKR $5.5(\mathrm{~m})$ was allocated to the contractor to construct a reinforced cement concrete (RCC) building. The contractor made substantial changes in the work scope. For instance, instead of concrete roofing, galvanized iron (GI) sheets were used. The $\mathrm{P} \& \mathrm{D}$ department discovered the usage of substandard materials in construction and misappropriation of funds was also reported in the project. The high public official visited the site and directed to initiate an inquiry. Nevertheless, construction of the project was resumed after several years with $70 \%$ additional allocation of funds that was completed in 2016 (Tajik, 2015). Although project monitoring systems existed in the national construction industry. The permanent monitoring staff was deployed on the project site for reporting the progress which was neglected. The overrun cost of the school project can be avoided if early identification was made. Such issues are very much prevalent in developing countries because the public project management practices are on the nascent stage and literature shows that project monitoring is undertaken for symbolic reasons, rather than a substantive measure to take corrective actions and found weak monitoring systems in projects (Lengwiler \& Wolfstetter, 2006).

The main research question is to find the impediments in the process of monitoring publicsector construction projects in Pakistan from the lens of transaction cost economics (TCE) theory. To address the research question, three objectives are formulated: first, to analyze the prevalent monitoring practices in the public sector construction industry of Pakistan. Second, to identify the significant factors which influence the project monitoring process. Third, to propose industry professional policy implications. This study provides significant unique contributions to the body of knowledge that argues that TCE theory provides primarily a guide to academicians to identify the gray areas of risk of cost escalation in the process of project monitoring. It also guides the practitioners in identifying potentially weak areas and suggested formulating the policies to make an effective monitoring process in construction projects its completion.

However, we take our initial step toward reviewing the literature from an organizational perspective. The endeavor is conducting an exploratory study. In the second step, the research methodology is provided. The third step elaborated upon the analysis and discussions of the research. The final step of the study will be concluded by identifying the organizational constraints that may cause weak monitoring resultantly TC enhances.

\section{Literature Review}

\section{Project Monitoring in contracting services}

Monitoring of the projects especially in the construction industry is one of the major phases of the project lifecycle. Construction organization deploys monitoring system after contracting out a project 
to monitor contractual performance. One of the main aims of contracting authorities in the process of monitoring is to ensure that contract agreement is accomplished with the pre-defined cost, time, and quality (Al-Jibouri, 2003). The construction organization's control is reinforced through the monitoring of performance on the project site which provides information on trends and variations in performance, which gives enough space and a possibility for early intervention and prompt remedial action. Despite the pre-establish monitoring mechanism in the organization, the relationship between the construction organization (Contractor) and management field staff is quite complex and problematic (Hall \& Rimmer, 1994). The pre-establish monitoring indicators have been a mechanism for coordination between the field monitoring staff and organization, which is often challenging because it ignores the efficiency of the project monitoring team. The lack of supporting services to the field monitoring staff may cause misreporting of project information, compromise on quality, and probable behavior of the contracting party in a transaction.

However, it is argued that construction organizations intend to solve the problems of the project staff and controlling prevailing deficiencies in the contract monitoring process to successfully achieve the monitoring activity but lack identifying the critical issues which influence the monitoring process. Notwithstanding the efforts promoting effective monitoring system, organizations are failing to provide the field monitoring staff with appropriate authority, decision powers, logistic support, and trust-based relationship consequently unsavory practices and opportunistic behavior of contractor continue in contracting practices which hinder the efficiency of monitoring systems (Smith \& Rosenblum, 2011). For instance, Linda (2009) investigated the humanitarian project in West Darfur, Sudan; however, one of the critical management issues was the lack of delegation of authority to the monitoring staff cause slow decision-making on emergent issues on project sites. Callistus and Clinton (2016) studied in Ghana found that weak organizational capacity, poor data quality, improper budgetary allocation, and limited resources are significant contributors to the implementation of project monitoring in the construction industry. In two different studies, Linda (2009) and Mcanulty and Baroudi (2010) found the project remoteness reduces the control of the project through established monitoring systems. They pinpointed the non-availability of infrastructure, and lack of trained human resources are the biggest impediment for the project progress supervision. Mcanulty and Baroudi (2010) researched the problems of remote construction projects. These were projects of different sizes mostly located in a remote and rough location, and terrains such as deserts and mountains. They found that these projects were environmentally challenging to reach for trading parties to monitor the work progress and most of the projects found delayed and cost overruns. Sometimes projects due to their remote locations may encounter logistic support, availability of specialized staff, and a shortage of materials to the contractor (L Kestle \& London, 2003). Nonetheless, if such projects are left unmonitored may fall prey to cost overrun, schedule delays, and deviations from the predefined standards.

Despite numerous problems in the monitoring process, it is considered an effective mechanism to control the project cost, schedule, and project objective (Al-Jibouri, 2003), and its realization would arguably be disrupted if the issues related to this phase of the project cycle is not adequately addressed. Therefore, it is necessary to investigate the construction project monitoring process, to understand the factors which undermine this vital phase of the project cycle. Drawing on the transaction cost economics theory (TCE), this study investigates the monitoring process of construction projects. It will help practitioners deriving strategies outset of the contracting to overcome the escalation cost of monitoring and administering services, often known as TC.

\section{Transaction Cost Economics Theory}

TCE is the neoclassical economic theory, a branch of an organizational theory that can better describe the problems that emerge in the project performance monitoring. In the literature, many researchers have studied the application of TCE as an interdisciplinary concept in the construction industry (Eccles, 1981; Gunnarson \& Levitt, 1982; Reve \& Levitt, 1984). Some researchers have studied the overall application of TC (Li, Arditi, \& Zang, 2013; Soliño \& Santos, 2008). Others have applied TC to pre and post-contract service delivery; for instance, researchers have focused on a pre-contract service delivery management system (Blanc-Brude, Goldsmith, \& Timo, 2006; Dudkin \& Välilä, 2005; Memili, Chrisman, Chua, Chang, \& Kellermanns, 2011; Vining \& Boardman, 2008). In the past few decades, TCE has become the leading theory applied in the field of organizational science. Keeping in view the preliminary idea of the application of TCE theory. This study believes that it can 
also be used as a framework to examine the challenges associated with the monitoring process in construction projects.

According to the TCE theory, the perfect agency in a contracting relationship is difficult to achieve between the principal (owner) and agent (contractor), if not impossible, because of attributes (bounded rationality and opportunism) and assumptions (human and environmental factor) associated with transaction framework. TCs is the result of an imperfect agency, where the owner's cognitive limitations (bounded rationality) and contractor (opportunism) rise the incomplete contracts between them (Greenwood \& Yates, 2006; Williamson, 1996). Williamson (1981) argued that bounded rationality is the cognitive limitation of either party to act as a well-informed agent. Opportunism is the individual endeavor for personal gain in the relationship, whereby the owner and contractor's goals do not coincide. It is expensive to manage the influence of bounded rationality and opportunism in any transaction because of the environmental factors (asset specificity, uncertainty, and frequency) (Williamson, 1981). Asset specificity refers to the extent to which the investments made to support a particular transaction have a higher value in that transaction than they would have if they were redeployed for any other purpose (Williamson, 1996). Asset specificity includes human specificity, i.e., human skills, competence, and learning (Masten, Meehan, \& Snyder, 1989), physical specificity is the requirement for resources and facilities (Caves \& Bradburd, 1988), and site-specificity in the geographically advantageous location, which is easy to access that can save transportation cost (Joskow, 1985) and dedicated and spatial specificity (Greenwood \& Yates, 2006). The focus of this study is on the first three types of asset specificity. The asset specificity, uncertainty, and frequency decide the form of governance and type of contract. For instance, if the asset specificity is low, high, or moderates the recommended form of governance is a market (classical contract), hierarchy (internal), and hybrid (neoclassical contract) respectively. This can be changed with the condition of uncertainty in the environment (David \& Han, 2004). For instance, when the asset specificity and uncertainty are high hierarchy form is preferred over market and hybrid form of governance. Thus, the interplay of asset specificity and uncertainty causes TCs (Donato, 2010). Hence, the governance choice is the interplay of asset specificity and uncertainty (David \& Han, 2004). There is a different elaboration of TCE theory that is not covered here. However, we focus on PWD as a case to test these tenets.

\section{Research Setting: A Case study of the Public Works Department}

To conduct this research, Public Works Department (PWD), a public sector construction organization is chosen. This organization contracting out infrastructure projects (roads, buildings, water supply, sanitation schemes, etc.) to the private contractors in the GB region. PWD is one of the largest publicsector organizations taking care of hundreds of small and large construction projects. This study investigates projects valued at less than PKR $500(\mathrm{~m})$. The proposed construction projects are first reflected in Annual Development Programme (ADP) for budgetary approval. The approved projects are contracting out by PWD through an open bid. The PWD is the nexus for contracts, and a Project Manager (PM) supervises multiple projects and monitors work progress through field staff (associateengineers).

The purpose to choose PWD as a case study was based on three factors. Firstly, PWD manages hundreds of projects at a time. It has a large number of employees and its employee turnover indicated that it is representative of the largest organization in Pakistan dealing with construction projects. The cases for data collection from this organization allowed us a case replication methodology to address the cross-case generalizability in findings (Yin, 2006). Secondly, this is one of the largest public sector organizations in the region. This organization deals with hundreds of construction projects. Finally, it is most likely that PWD cases can be applied for developing countries particularly the South Asia region because project management practices in these countries face similar social, political, financial, and cultural challenges which drive it to poor project management performance (Cusworth \& Franks, 2013). Therefore, the PWD experience provides a base for the developing countries' context to address the issue which is our intention to explore.

\section{Research Methodology}

This study was conducted to identify organizational difficulties in monitoring contractors' performance during the execution of projects, as it incurs TCs in construction projects. The research was conducted in PWD that manages hundreds of small and large construction projects in the region. During interviews, the participants refused to have the interview sessions recorded. Thus, two 
scholars were hired for note-taking. After the interview, each interview was transcribed using a word processor. The nature of the study warrants us maintaining the confidentiality of the interviewees and the hierarchical departments of PWD. In total, twenty-five interviews were conducted with the Project Managers (PM) and Associate Engineers drawn from three organizational departments (called ALPHA, BRAVO, and CHARLIE), as shown in Table 1, from 6 districts (labeled as A, B, C, D, E, and F) of GB. For detailed exploration, we opted for a case study and triangulated between evidence gathered from multiple sources (Hesse-biber Nagy \& Leavy, 2010; Yin, 2006). The research was exploratory and drew on interpretivist epistemology, which helped us to understand the multiple realities in the process of project monitoring. To enhance the study's reliability, we followed (Yin, 2006), who suggested developing a detailed case study protocol and taking a systematic approach to compiling the case study database. Two different interview protocols were prepared for the PM and associate-engineer in this study, including questions eliciting a focal project's profile, aims, and objectives; interview questions details and their explanations, and filed procedures for an interview, etc.

The interviews were conducted from 6 districts of the GB. A personal visit was made to conduct these interviews. Each interviewee was approached personally and took formal consent for the interview. In the interview protocol, interviewees were asked a combination of 11 open-ended and closed-ended questions. To enhance validity and ensure internal consistency, a pilot study was conducted from selected informants (Yin, 2006). In this study, similar interview questions were asked from the PM and associate engineers who deal with the construction project in PWD. The PM Interview protocol consists of questions that broadly cover the monitoring process at the organizational level; for instance; we asked "How do you monitor work progress on the project worksite? How do you confirm that field supervisory staff is monitoring the project work? How do you confirm the field report and actual project progress on site?" The Associate Engineer interview protocol covers the questions regarding their monitoring responsibilities on the project site. We asked, for instance, "What is a mechanism to check the quality of work on the project site? What problems do you face during the monitoring process?" Follow-up questions were also asked during the interview to elicit more detailed answers. The interviewees were asked for elaboration based on facts, experiences, incidents, problems, and issues pertinent to project performance monitoring as manifested during their visits to the projects. Construct validity was assured through the use of multiple sources of evidence, which included non-participant observation and archival data analysis (Yin, 2006). Triangulation allowed us to contrast and compare the contractor's reports with the actual working conditions (Table 2). Our face-to-face interview notes and field observation notes were transcribed using a word processor.

In this research, the unit of analysis is post-contract contracting of the public sector construction projects. We used an inductive approach in conducting the qualitative content analysis. In the inductive approach, the codes, categories, and themes were drawn directly from the transcripts (interviews, field notes, site observation notes) that have the potential to extract both latent and manifest content (Cho \& Lee, 2014). For our study, an independent scholar was assigned to conduct the first cycle of open coding from transcripts. In this process, every line on the transcript is read and marked with the appropriate code. It is followed by the second cycle coding combing the codes with similar meaning and connotation (Weber, 1990) are classified into the preliminary code. For instance, a shortage of material testing laboratory and lack capacity of the testing laboratory can be placed under one code. In the process of coding, several codes may be left to get a place in a group that was further securitized for their classification otherwise removed. We have also made sure that not a single item falls into two codes. Following the same procedure, similar codes are classified into the theme which links the underlying meaning together in categories (Graneheim \& Lundman, 2004). Thus, identified themes through a systematic process that influence project performance monitoring in contracting projects was concisely named (Table 3 ). The findings were verified by recently retired senior officials of the department to obtain their fair view of the outcomes.

\section{Table 1}

Schedule of project characteristics

\begin{tabular}{llll}
\hline Description & Project ALPHA & Project BRAVO & Project CHARLIE \\
\hline Project type & School building & Water supply & Road maintenance \\
Nature of work & New building & New water supply & Old road maintenance
\end{tabular}




\begin{tabular}{llll} 
Contracting type & Single contracting & Multiple contracting & Single contracting \\
Contractor status & Certified contractor & Certified contractor & Certified contractor \\
Contractor selection & Competitive & Competitive & Competitive \\
& Tendering & Tendering & Tendering \\
\hline
\end{tabular}

\section{Table 2}

Schedule for Key Informant Types and Interview Data Collection

\begin{tabular}{|c|c|c|}
\hline Data Collection & Project Manager & Sub-engineer \\
\hline & ALPHA 2 & ALPHA 2 \\
\hline \multirow{2}{*}{ interviews } & BRAVO 2 & BRAVO 2 \\
\hline & CHARLIE 2 & CHARLIE 2 \\
\hline \multirow[t]{3}{*}{ Site Observation } & 2 times visit. & 1-time visit \\
\hline & Field Officer & with contractor \\
\hline & Field Officer & \\
\hline Non-Participant & Manager (2 times) & Manager (1 time) before the interview \\
\hline Observation & 1 for appointment & Field officer (3 times) \\
\hline (Manager \& Sub- & 1 before interview & 2 for meeting \\
\hline Engineer & Field officer (2 times) & 1 for site visit \\
\hline $\begin{array}{l}\text { Archival Data } \\
\text { Analysis }\end{array}$ & $\begin{array}{l}\text { Project agreements, quarterly field reports, } \\
\text { project completion reports, monitoring } \\
\text { reports, consolidated data of project } \\
\text { reporting, and complementary information } \\
\text { gathering }\end{array}$ & $\begin{array}{l}\text { Monthly reports, project completion } \\
\text { report, field book, worksheet }\end{array}$ \\
\hline
\end{tabular}

\section{Analysis and Discussion}

There is a significant gap between the normative method of project monitoring in the engineering literature, i.e., the Pakistan Engineering Council (PEC), and actual practices at the project site. The general monitoring literature specifies comprehensive and rational mechanisms that require extensive resources. Constraints restrict project monitoring on project sites. The dominant factors for project monitoring that incur TCs are attributed to many influences. It may be that idealistic monitoring practices remain unrealistic and are seldom attainable, but poorly adopted monitoring is better than none because it aligns the executor with the contract terms and conditions. The TCs incurred by organizations might be the result of many direct as well indirect influences during the process of contracting. The leading critical themes that impact the post-contract TCs in construction projects are identified below (Table 3).

\section{Political reality}

Economic viability is the primary consideration in a project concurrently it becomes part of the political agenda in a government of any developing country (Ho, Levitt, Tsui, \& Hsu, 2015). The influences of the political elite are common in construction projects, and the current study identifies them as significant impediments to project monitoring. The relations of the political elite with private (contractor) individuals help politicians in their political campaigns by providing financial and human resources (Flyvbjerg \& Molloy, 2011; Osei-Tutu, Badu, \& Owusu-Manu, 2010). The contractors, in exchange, obtain private gains from public offices.

One respondent indicated that the 'sub-engineer gave a hard time to the contractor regularly monitoring the project site. It stopped him (contractor) from manipulating the specifications, so the contractor used political influences to transfer his services to hard areas'. Similarly, the political elite's relationship with PMs is for their mutual benefit. The PM, on politician's recommendations, makes full and advance payments to the contractor, though the contract work is incomplete.

Another respondent said, 'We had a building construction project at PKR 7 (m) near XYZ place; because of the contractor's political influence, we paid the full amount, on the ground, the work was not completed. In return, the PM uses political sources to transfer PM or sub-engineer services to an appropriate district. Another respondent replied that 'my position in this place is political; even my posting, promotion, and my placement is based on my political affiliation.' In such situations, contractors receive the full payment whether work on the project site is completed or not.

Frequent military takeovers in Pakistan have destroyed the welfare-centric political fabric and replaced it with the feudal culture of politics; this is evident in every sphere of life, including public office (Imam \& Dar, 2014). While most of the respondents expressed that political influences in public offices, even in administrative affairs, challenge project monitoring. Political influences 
develop informal constraints, and formal rule violations enhance uncertainty (behavioral and environmental) for project monitoring. The politician's relationship with PMs, contractors, and public officials in administrative matters helps opportunists gain extras. In the market type of arrangement, the degree of uncertainty does not play a crucial role unless asset specificity is low because both parties make the necessary arrangements (David \& Han, 2004), but in the current situation, asset specificity is high. Political influence in public offices causes hold-up problems for both parties and makes it difficult for the PM to maintain an arm's length relationship with the contractor on such issues. Opportunists in these conditions actively start negotiating, initially for time extensions with the expectation of renegotiating rates in the future. Political manipulation in public offices causes TCs to increase.

\section{Table 3}

List of factors influencing monitoring in the contracting services of construction projects.

\begin{tabular}{|c|c|c|}
\hline $\begin{array}{ll}\begin{array}{l}\text { Influencing } \\
\text { (latent content) }\end{array} & \text { Factors } \\
\end{array}$ & Characteristics of influencing factors ( & manifest content) \\
\hline \multirow[t]{5}{*}{ Political Realities } & - & Politician relationship with the PM \\
\hline & - & Politician relationship with the contractors \\
\hline & - & Political influence within public offices \\
\hline & - & Nexus between contractor and PM \\
\hline & - & Vested interest groups influencing bidding \\
\hline \multirow[t]{5}{*}{ Capacity Building } & and non-technical) & Lack of skilled labor and staff (technical \\
\hline & - & Lack of employee training \\
\hline & - & Non-transparent hiring \\
\hline & - & Resource-deficient laboratories \\
\hline & - & Non-transparent hiring \\
\hline \multirow[t]{6}{*}{ Resource Constraints } & - & Non-availability of testing equipment \\
\hline & - & Obsolete technology \\
\hline & - & Insufficient logistical support \\
\hline & - & Shortage of employees \\
\hline & - & Lack of support facilities (fuel and \\
\hline & - $\quad$ transportation charges) & Inadequate IT support systems for \\
\hline \multirow[t]{5}{*}{ Administrative Issues } & payment) & Late payment to the contractor (block \\
\hline & department (PWD) & Inappropriate timing of fund release to the \\
\hline & - & Conformity to the payment schedule and \\
\hline & seasonal constraints & Severe weather conditions hampering \\
\hline & project work and monitoring. & Accessibility issues to remote areas \\
\hline \multirow[t]{5}{*}{ Mutual Dependency } & - & Official use of contractor resources for site \\
\hline & - $\quad$ (measurement of bills (MBs) & Official staff on contractor payroll \\
\hline & - & Rule violations to avoid budget lapses. \\
\hline & - & Allocation of commission for officials \\
\hline & $(\mathrm{PWD}, 2 \%)$ & \\
\hline \multirow[t]{4}{*}{ Lack of Coordination } & department (P\&D and PWD) & Lack of communication amongst the \\
\hline & - & Payment rate issues (market vs. official) \\
\hline & (Federal Government) & Delays in fund release from a donor \\
\hline & 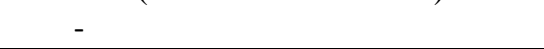 & Post-contract negotiations \\
\hline
\end{tabular}

\section{Capacity Building}

Monitoring requires specialized technical skills, and without skill development, it can be challenging for staff (Brown \& Potoski, 2005). Following the economization of transactions, the current project 
monitoring systems lack a capacity for execution, which potentially causes TCs. The associate engineers are deputed on the project sites for the monitoring of work's progress (PEC, 2009).

One of the respondents said that 'we are fresh graduates and more enthusiastic, though, in our job. They (PMs) give more weight to the contractor's experience over our education. Perhaps we do not have much experience in this field'. Monitoring can be more prone to post-contract manipulation by opportunists if the monitoring staff is less experienced and not equipped with the required skills and technology or the associated monitoring facilities.

Another respondent says, 'In the previous government tenure, much hiring in the department was political, individuals were hired without any test or interview. They (sub-engineers) do not have the capacity; how we can expect something good from them in the process of monitoring?' Similarly, another respondent observed that the 'test laboratory cannot conduct the test; we manually check the material used on the project site.' Although project governance is practiced on the project sites, albeit slowly. It shows the lack of facilities for project monitoring. Proper project monitoring requires appropriate capacity building and the availability of resources associated with this process.

Project management practices are in their nascent stage in Pakistan. The corrupt bureaucratic practices lead inexperienced and inefficient public servants to be appointed to public offices (Lambsdorf, 2006) is the bigger challenge for the monitoring process. The respondents found that issues with the support facilities for monitoring, such as small testing laboratories, shortage of skilled labor, lack of employee training, and political hiring, put the monitoring process at risk. The TCE theory describes in the current situation that, the degree of asset specificity (human and physical) and uncertainty (behavioral and environmental) is high. The organization can face additional costs from shirking due to the weak capacity of the monitoring team. A deficient monitoring staff with insufficient skills leads to uncertainty (behavioral and environmental) because pre-contract instructions are avoided in the post-contract transactions. The shirking problem may cause the opportunistic behavior of the contractor that leads to unsatisfactory performance (Han et al., 2007). Capacity constraints for monitoring are an issue identified by the respondents that increase TCs. Construction management requires adjustments and adaptation in post-contract governance (Yates, 1999), for instance, existing staff skill improvements, equipping the staff with current technological skills, the introduction of new technology, and increasing the number of functional laboratories in different areas.

\section{Resource Constraints}

A mismatch of demand and supply of services due to economic impediments may cause severe challenges for the government while implementing governance (Pal, 2013). In local monitoring processes, shortcomings in resources found which may curtail the efficiency of monitoring at project sites. An increase in new projects in the ADP does not correspond to the rise in the number of employees for monitoring in the department, resulting in a deficiency of monitoring staff at project sites.

Regarding the shortage of employees, one respondent describes the current context: "Although I know the work is going on at various sites, how can I supervise 110 projects with one engineer and four sub-engineers?"

Another respondent states that, "We are instructed to visit the project site daily, but we do not, because our responsibilities are diversified, and we usually go together (PM and sub-engineer) to visit the projects sites once a day because we have only one vehicle, which can be used for one task at a time."

Similarly, another respondent noted, "The only laboratory in the region is not functional. Most of the testing equipment is outdated or not available. If I want to test asphalt temperature, I do not have a required thermometer. I check it using a shovel; how can I perform better? How could I conduct proper monitoring?"

One of the significant reasons for resource shortage in the public departments of developing countries is budgetary cuts because of financial constraints (Lambsdorf, 2006). Pakistan's fiscal deficiencies are compensated by foreign debt. The fiscal constraints and financial mismanagement in ministries have trickle-down effects on the allocation of budgets for development projects with a shortage of resources. Respondents argued that sites are left unmonitored because of staff shortages, a lack of logistical support, outdated technology, poor support facilities, and the non-availability of equipment in public offices. TCE theory, in this situation, would note the high degree of asset 
specificity (human, physical, and site). According to the respondents, opportunism is expected because of insufficient monitoring skills, a shortage of employees for monitoring and inadequate resources in the organization can be exploited on the project site. Infrequent project site visits due to resource constraints may cause information asymmetry and moderate opportunistic behavior of the contractor because the frequency of project site visits may be reduced but not stopped. Fewer site visits minimize control and coordination in their relevant area and allow agents to benefit through unidentified advantages (Osei-Tutu et al., 2010). The construction industry, in general, is laborintensive and requires technical skills, the absence of which increases TCs. A similar finding was reported in Uganda, where a shortage of employees was one major determinant of low monitoring in projects (Hardlife \& Zhou, 2013).

\section{Administrative Issues}

Contractor performance monitoring in public offices requires complete contracting services and institutional arrangements in the private sector (Miranda \& Lerner, 1995). Internal regulatory issues on the part of the PM decrease the legitimacy and likelihood of the proper monitoring of projects, for instance, a failure to provide financial resources to the contractor according to the contract terms.

One respondent replied, 'Usually, the general perception that the contractor does not complete their project on time is not true; it is the department (PWD) that does not make timely payments to them (contractor) upon completed work, resulting in project delays.'

Some pre-contract issues lock the project monitoring. For instance, to hide organizational inefficiency in timely budgetary allocation, the PM may cast aside legal procedures and allocate the project budget to contractors. Another respondent explains that the "last week of the last month of a financial year is very crucial for us. As a XEN (PM), I have to stay in the office to utilize the remaining funds for different projects. Otherwise, it will lapse'.

Another respondent says, 'to protect again the budgetary lapses, we do two things: either make full payments in advance for new projects or make payments for incomplete work. Otherwise, the money will lapse'.

In Pakistan, weak institutional governance is one of many reasons for administrative problems in public office (Anwar, 1998). The institutional framework and weak institutional management provide opportunities to exploit resources and violate rules (North, 1990). However, respondents found delays of fund release from the federal government which influence the payments to the contractor before the severe weather condition start and construction work stopped. Thus, the problems created by the organization due to weak administration is a significant hurdle for the monitoring staff in their attempts to follow the strict schedule and to maintain an arm's length relationship with contractors.

Respondents also pointed out administration issues, for example, illegal advance payments, late payments, and the failure of PMs to align the timing of fund release with seasonal constraints. From the TCE perspective, there is a high degree of asset specificity and uncertainty. This situation brings exchange hazards in which one party's opportunistic behavior can be mitigated by a high TC. Post-contract formal rule violations from both sides create informal relationships between the contracting parties that lead to shirking problems for the monitoring staff. Internal administrative weaknesses place the PM in a more accommodating position in a trading relationship. An opportunist contractor in this volatile situation may have incentives to hold up transactions to gain benefits from the organization. The delay payments encourage the contractor to make additional claims; further, a shortage of construction time starts renegotiations that lead to demand for compensatory incentive payments, which escalate the TCs. The organizational archival data show that more than $80 \%$ of projects are not completed on time and request for time extensions; further, more than $60 \%$ of projects demand revised rates. Other studies also confirm that inefficient administrative weakness causes project additional cost (Rajeh, Tookey, \& Rotimi, 2015), and project cost overages range from $40 \%$ to $200 \%$ in public projects (Williams, 2005). The inefficiency in monitoring these projects can cause serious time overages, cost overages, and quality issues, which are the primary concerns in projects (Yu, Flett, \& Bowers, 2005).

\section{Mutual Dependency}

The nature of the relationship between the contracting parties depicts the efficiency of the organization's monitoring process. Given the omission of pre-contract arrangements (Klein, Crawford, \& Alchian, 1978; Williamson, 1979), causes post-contract mutual dependency of 
contracting parties. The contractor attracts a monitoring team with incentives that put the monitoring process at stake.

One of the respondents replied, 'Preparing the bill is the contractor's technical staff's responsibility, but they do not hire them for their projects because of financial constraints.' Therefore, the project monitoring staff covers the contractor competence deficit, providing the technical assistance (preparing MBs and technical advice) for a commission (2\% of the total project cost) paid by the contractor on every project. Because of department resource constraints, the PM also uses the contractor's resources (logistics) for official project site visits and sometimes for personal use. An opportunistic contractor will strive to promote their interests in such contracting situations (Lamothe \& Lamothe, 2012).

Another respondent argued that 'to show our annual budgetary performance, we have to allocate the budget at the eleventh-hour during June, and the same month, the contractor shows performance on paper only. After these delaying practices, how can we ask from the contractor regarding their performance?' The contractor accepts this offer, knowing the time limitation for project execution, with the expectation of future settlements and renegotiations.

Public project management practices in Pakistan face many challenges because of monopolies, a rigid organizational structure, and political influence (Boyne, 2002). In this situation, the institutional framework is open to easy exploitation. The respondents found that the institutional framework of formal laws has been replaced by informal rules that promote rent-seeking, as discussed by North (1990). Grossman and Hart (1986) argued that TCE does not clearly explain how to address this type of relationship when the self-interested owner becomes the self-interested employee of the other party. According to TCE theory, asset specificity is high in the given situation, and transactions would be highly idiosyncratic if either party invests because, for them, it is worth more to make an investment within the relationship than outside of the relationship (Grossman \& Hart, 1986). David and Han (2004) contended that high asset specificity increases mutual dependency which is found in the given circumstances. For instance, the officials use contractor resources and provide technical assistance, i.e., preparing MBs, in return for the contractor's offer of a fixed commission (2\%) and logistic support for official and personal use. The opportunistic behavior of either or both parties shows high uncertainty; therefore, relation-specific bargaining of both contracting parties begins. In this case, formal rules are replaced with informal constraints that enhance the costs of shirking. The opportunistic relationship between the contractor and monitoring staff potentially tends toward inhouse maladaptive activities, which have TCs. Many studies supported this finding (Lee et al., 2009; Osei-Tutu et al., 2010).

\section{Lack of Coordination}

The cost of coordination sometimes increases more than the benefits derived from it (Cavinato, 1992). In our context, the enforcement of monitoring is indirectly influenced by a lack of intra-department coordination (between the PWD and Revenue Department) in an ambiguous organizational environment. If the project execution stopped because a sister department (Revenue Department) delays payment for the acquisition of the project site, thus, the project monitoring process becomes dysfunctional. These issues arise because of an intra-department communication gap.

One respondent said that 'there was road construction in District XYZ. The landowner stopped contractor work and demanded compensatory payments on market rates. Therefore, we had to stop the work and apply for a rate revision from the chief secretary's (a higher authority at the Revenue Department) office'.

The PWD after bidding supervises the project's progress, and the sister department mostly takes an unexpectedly long time to settle compensatory payments due to lengthy official procedures. These delays incur three forms of TCs: the revision of property rates (landowner), the review of contract rates (contractor), and the litigation cost on the project. However, respondents believed that lack of organizational department coordination puts project monitoring at stake. TCE theory, applied to such situations shows a high degree of asset specificity because deployed resources do not have alternate uses until these issues are settled, and the project starts. The contracting parties encounter post-contract difficulties in adhering to the pre-contract arrangements that increase uncertainty which provides a cushion for the agent to act opportunistically (Grossman \& Hart, 1986; Williamson, 1979). In the prevailing situation, post-contract renegotiations start between contracting parties, leading to costly haggling and increases in the TCs (Jobin, 2008). An opportunistic contractor may demand time 
extensions and make additional claims. Additional work is requested with a vague description after the contract is finalized. It changes the work specifications, provides space for the contractor to manipulate the quality, quantity, and credibility of the bills submitted for claim. The organization incurs TCs from late compensatory payments to the landowner because of a difference in property rate issues (official vs. market), and revisions of the contract rates. Hence, the lack of department coordination has TCs which can be verified from other studies (Anderson \& Buvik, 2001; Artz \& Brush, 2000; Jobin, 2008).

\section{Conclusion, limitations, and future research}

The main purpose of this research was to open the monitoring black box of an organization and its associated costs. In doing so, TCE as a theoretical approach was applied to the formal and informal elements of transactions. In this qualitative study, twenty-five interviews were conducted from different sections of an organization to ascertain the impediments in the process of project monitoring. This study finds that the efficiency of the monitoring process is not acquired just by establishing a mechanism rather particular emphasis is needed on providing sufficient resources with the appropriate authority. This study offers some useful insight into project governance with specific emphases on the project monitoring process. The respondents understood the importance of project performance monitoring as part of project management. The findings indicate that a clear pre-contract arrangement is essential for post-contract oversight to limit opportunistic behavior. The contribution of this research is twofold. First, it determines the expected potential influencing factors for project monitoring that directly and indirectly affect TCs. Project monitoring in Pakistan would be bounded if political realities, capacity building, resource constraints, administrative issues, mutual dependency, and departmental coordination factors were not strictly observed. Second, this investigation found that expected post-contract TCs are predominant because of loosely practiced monitoring processes. Thus, formal project monitoring needs pre-contract organizational support to ensure post-contract enforcement otherwise it would be a formality rather than an obligation resultantly monitoring can be sloppily executed.

This research will help practitioners and academicians to make improved decisions in contexts where project performance monitoring is more sensitive to internal and external influences, which lead to a substantial escalation of total project costs. This study takes the organizational perspective and concludes that due to high asset specificity and uncertainty, TCs are high in the current form of governance (market). However, because of the rigid organizational structures in the public sector organizations, the prevailing market form of governance is not easy to replace but can be improved by providing adequate resources. The industry practitioners can use these findings as a basis for effective post-contract planning for project monitoring and enforcement to reduce the cost escalation. It is indeed true that TCE theory is not a panacea. Its application does not guarantee the explanation of all factors associated with a transaction, but it has the potential to allow decisionmaking on economic grounds. This study makes an academic contribution identifying the critical hindrances for the project monitoring in the construction management for cost rationalization. This theory can be used in the future for similar situations.

There are, however, some limitations to the research findings. First, this exploratory study has used qualitative research with a limited number of respondents. It could be improved by increasing the number of cases and by formulating hypotheses and propositions to generalize the outcome for a broader population. Indeed, the beauty of case study research is in the collection of data from a more extensive research area for analysis reaching significant results (Yin, 2006). Second, this framework provides value when researchers test the findings with rigor incorporating qualitative and quantitative studies in different research settings. Third, this research used only the organizational perspective of contracting services. In the future, richer identification and analyses can be made by incorporating the contractors' and consultants' views. Finally, capturing only public sector project monitoring processes is insufficient for drawing proper conclusions unless integration of the private sector monitoring process because of environmental differences between public and private sector construction projects.

\section{Reference}

Abbot, J., \& Guijt, I. (1998). Changing views on change: participatory approaches to monitoring the environment. SARL Discussion paper.

Abdul-Rahman, H., Berawi, M. A., Berawi, A. R., Mohamed, O., Othman, M., \& Yahya, I. A. (2006). Delay mitigation in the Malaysian construction industry. Journal of Construction Engineering 
and Management, 132, 125-133.

Al-Jibouri, S. H. (2003). Monitoring Systems and their Effectiveness for Project Cost Control in Construction. International Journal of Project Management, 21(2), 145-154.

Anderson, O., \& Buvik, A. (2001). Inter-firm coordination: International versus domestic buyer-seller relationships. Omega, 29, 207-219.

Anwar, S. (1998). Fostering fiscally responsive and accountable governance: Lessons from decentralization. In R. Picciotto \& E. Wiesner (Eds.), Evaluation and Development: The Institutional Dimension (p. 338). Transaction Publishers.

Artz, K. W., \& Brush, T. H. (2000). Asset specificity, uncertainty, and relational norms: an examination of coordination costs in collaborative strategic alliances. Journal of Economic Behavior \& Organization, 41(4), 337-362.

Avery, G. (2000). Outsourcing public health laboratory services: A blueprint for determining whether to privatize and how. Public Administration Review, 60(4), 330-337.

Blanc-Brude, F., Goldsmith, H., \& Timo, V. (2006). Ex-ante construction cost in the European road sector: A comparison of public-private partnership and traditional public procurement. $E I B$ Economic and Finance Report No. 2006/1.

Bower, D. C., \& Finegan, A. D. (2009). New approaches in project performance evaluation techniques. International Journal of Managing Projects in Business, 2(3), 435-444.

Boyne, G. A. (2002). Public and private management: What's the difference? Journal of Management Studies, 39, 97-122.

Brown, T. L., \& Potoski, M. (2003). Managing Contract Performance: A Transaction Costs Approach. Journal of Policy Analysis and Management, 22(2), 275-297.

Brown, T. L., \& Potoski, M. (2005). Transaction Cost and Contracting: The Practitioner Perspective. Public Performance \& Management Review, 28(3), 326-351.

Callistus, T., \& Clinton, A. (2016). Evaluating Barriers to Effective Implementation of Project Monitoring and Evaluation in the Ghanaian Construction Industry. Procedia Engineering, 164(June 2017), 389-394.

Caves, R. E., \& Bradburd, R. M. (1988). The empirical determinants of vertical integration. Journal of Economic Behavior \& Organization, 9(3), 265-279.

Cavinato, J. L. (1992). The Total cost/value model for supply chain competitiveness. Journal of Business Logistics, 13, 285-301.

Cho, J. Y., \& Lee, E. H. (2014). Reducing confusion about grounded theory and qualitative content analysis: Similarities and differences. Qualitative Report, 19(32), 1-20.

Cusworth, J. W., \& Franks, T. R. (2013). Managing projects in developing countries. Routledge.

David, R. J., \& Han, S. K. (2004). A systematic assessment of the empirical support for transaction cost economics. Strategic Management Journal.

Donato, R. (2010). Extending transaction cost economics: Towards a synthesized approach for analyzing contracting in health care markets with experience from the Australian private sector. Social Science \& Medicine, 71, 1989-1996.

Dudkin, G., \& Välilä, T. (2005). Transaction cost in public-private partnership: A first look at the evidence. EIB Economic and Finance Report No. 2005/03. Luxemburg: European Investment Bank.

Eccles, R. G. (1981). The quasi-firm in the construction industry. Journal of Economic Behavior and Organization, 2(4), 335-357.

Flyvbjerg, B., \& Molloy, E. (2011). Delusion, deception, and corruption in major infrastructure projects: Causes, consequences, and cures. In S. Rose-Ackerman \& T. Søreide (Eds.), International Handbook on the Economics of Corruption, (vol. 2, pp. 81-107). Cheltenham: Edward Elgar Publishing Ltd.

Graneheim, U. H., \& Lundman, B. (2004). Qualitative content analysis in nursing research: concepts, procedures, and measures to achieve trustworthiness. Nurse Education Today, 24(2), 105-112.

Greenwood, D., \& Yates, D. J. (2006). The determinants of successful partnering: A transaction cost perspective. Journal of Construction Procurement, 12(1), 4-12.

Grossman, S. J., \& Hart, O. D. (1986). The costs and benefits of ownership : A theory of vertical and lateral integration. Journal of Political Economy, 94(4), 691-719.

Gunnarson, S., \& Levitt, R. E. (1982). Is a building construction project a hierarchy or a market? 7th 
Internet Congress, Copenhagen.

Hall, C., \& Rimmer, S. J. (1994). Performance monitoring and public sector contracting. Australian Journal of Public Administration, 53(4).

Han, S. H., Asce, M., Park, S. H., Kim, D. Y., Kim, H., \& Kang, Y. W. (2007). Causes of bad profit in overseas construction projects. Journal of Construction Engineering and Management, 133, 932-943.

Hardlife, Z., \& Zhou, G. (2013). Utilization of monitoring and evaluation systems by development agencies: The case of the UNDP in Zimbabwe. American International Journal of Contemporary Research, 3(3), 70-83.

Hesse-biber Nagy, S., \& Leavy, P. (2010). The practice of qualitative research. SAGE, Publication, Inc.

Ho, S. P., Levitt, R., Tsui, C., \& Hsu, Y. (2015). Opportunism-focused transaction cost analysis of public-private partnerships. Journal of Management in Engineering, 31(6), 1-11.

Imam, A., \& Dar, R. A. (2014). Democracy and public administration in Pakistan. New York: CRC Press, Taylor \& Francis Group.

Jobin, D. (2008). A Transaction cost-based approach to partnerships performance evaluation. Evaluation, 14(4), 437-465.

Joskow, P. L. (1985). Vertical Integration and Long-term Contracts: The Case of Coal-burning Electric Generating Plants. Journal of Law Economics, \& Organization, 1(1), 33-80.

Kestle, L, \& London, K. (2003). Remote site design management-the application of case study methodology. In the proceedings of the Post Graduate Construction Research Conference.

Kestle, Linda. (2009). Remote Site Design Management. (Doctoral Dissertation, University of Canterbury, New Zealand).

Khoshgoftar, M., Bakar, A. H. A., \& Osman, O. (2010). Causes of Delays in Iranian Construction Projects. International Journal of Construction Management, 10(3), 285-295.

Klein, B., Crawford, R. G., \& Alchian, A. A. (1978). Vertical integration, appropriable rent, and the competitive contracting process. Journal of Law and Economics, 21(2), 297-326.

Lambsdorf, J. G. (2006). Causes and consequences of corruption: What do we know from a crosssection of countries? In S. Rose-Ackerman (Ed.), International Handbook on the Economics of Corruption (p. 655). Northampton, MA: Edward Elgar Publishing Ltd.

Lamothe, M., \& Lamothe, S. (2012). What determines the formal versus relational nature of local government contracting? Urban Affairs Review, 48(3), 322-353.

Lee, H., Seo, J., Park, M., Asce, M., Ryu, H., Ph, D., \& Kwon, S. (2009). Transaction-Cost-Based Selection of Appropriate General Contractor-Subcontractor Relationship Type. Journal of Construction Engineering and Management, 135(11), 1232-1240.

Lengwiler, Y., \& Wolfstetter, E. (2006). Corruption in procurement auctions. In N. Dimitri, G. Piga, \& G. Spagnolo (Eds.), Handbook of Procurement-Theory and Practice for Managers. New York: Cambridge Univerity Press.

Li, H., Arditi, D., \& Zang, Z. (2013). Factors that affect transaction costs in construction projects. Journal of Construction Engineering and Management, 139(1), 60-68.

Lobb-rabe, A. (2000). Impact Assessment with a Poverty Focus in Policy Advisory Projects: Concepts, Questions, and Cases. Hainburg, Germany: (GTZ) GmbH.

Masten, S. E., Meehan, J. W., \& Snyder, E. A. (1989). Vertical integration in the U.S. auto industry. A note on the influence of transaction-specific assets. Journal of Economic Behavior and Organization, 12(2), 265-273.

Mcanulty, S., \& Baroudi, B. (2010). Construction Challenges in Remote Australian Locations, (September), 1247-1257.

Meeampol, S., \& Ogunlan, S. O. (2009). Journal of Financial Management of Property and Construction Article information: Private Equity Investment and Real Estate Development: Evidence from Residential Projects in India, 19(3), 202-225.

Meeampol, S., \& Ogunlan, S. O. (2014). Private equity investment and real estate development evidence from residential projects in India. Journal of Financial Management of Property and Construction, 19(3), 202-225.

Memili, E., Chrisman, J. J., Chua, J. H., Chang, E. P. C., \& Kellermanns, F. W. (2011). The determinants of family firms' subcontracting: A transaction cost perspective. Journal of Family 
Business Strategy, 2, 26-33.

Miranda, R., \& Lerner, A. (1995). Bureaucracy, organizational redundancy, and the privatization of public services. Public Administration Review, 55(2), 193-200.

Nicholas, J. M., \& Steyn, H. (2012). Project Management for Engineering Business and Technology (4th ed.). USA: Routledge.

North, C. D. (1990). Institutions, institutional change, and economic performance. In A. Alt, James \& D. C. NORTH (Eds.), The political Economy of Institutions and Decisions (pp. 318-319). Cambridge: Cambridge Univerity Press.

Osei-Tutu, E., Badu, E., \& Owusu-Manu, D. (2010). Exploring Corruption Practices in Public Procurement of Infrastructural Projects in Ghana. International Journal of Managing Projects in Business, 3(2), 236-256.

Pal, L. A. (2013). Beyond policy analysis: Public issue management in turbulent times. Scarborough: Nelson Education Ltd.

PEC. (2009). Standard procedure pre-qualification of constructor. Islamabad: Pakistan Engineering Council.

Rajeh, M., Tookey, J. E., \& Rotimi, J. O. B. (2015). Estimating transaction costs in the New Zealand construction procurement. Engineering, Construction and Architectural Management, 22(2), 242-267.

Reve, T., \& Levitt, R. E. (1984). Organization and governance in construction. International Journal of Project Management, 2(1), 17-25.

Seasons, M. (2003). Monitoring and evaluation in municipal planning. Journal of American Planning Association, 69(4), 430-440.

Smith, E., \& Rosenblum, P. (2011). Enforcing the rules: Government and citizen oversight of Mining. New York, USA.

Soliño, S. A., \& Santos, P. G. de. (2008). Transaction costs in PPP transport infrastructure projects: Comparing procurement procedures. Kirchberg, Luxembourg: Working paper, European Investment Bank.

Tajik, F. A. (2015). Fund misappropriation: Planning \& Development Department, Gilgit-Baltistan rejects the new Building of Govt Boys High School Sost. Retrieved from http://sosttoday.com/fund-misappropriation-planning-development-department-gilgit-baltistanrejects-new-building-govt-boys-high-school-sost/\#.WeGF38lrzIU

Vining, A. R., \& Boardman, A. E. (2008). Public-private partnerships : Eight rules for Governments. Public Works Management \& Policy, 13(2).

Weber, R. P. (1990). Basic content analysis. London, UK: SAGE Publications, Inc.

Williams, T. (2005). Assessing and moving on from the dominant project management discourse in the light of project overruns. IEEE Transactions on Engineering Management, 52(4), 497-508.

Williamson, O. E. (1979). Transaction-cost economics: The governance of contractual relations. Journal of Law and Economics, 22(2), 233-261.

Williamson, O. E. (1981). The economics of organization: The transaction cost approach. American Journal of Sociology, 87(3), 548-577.

Williamson, O. E. (1996). The mechanism of Governance. New York: Oxford University Press.

Yates, D. J. (1999). Conflict and disputes in the development process: A transaction cost economics perspective. working paper, Department of real estate and construction, University of Hong Kong, Hong Kong.

Yin, K. R. (2006). Case study research design and methods. SAGE, Publication, Inc.

Yu, A. G., Flett, P. D., \& Bowers, J. A. (2005). Developing a value-centered proposal for assessing project success. International Journal of Project Management, 23, 428-436. 